\title{
The introductions of foreign technologies and managerial institutions: A case of Mitsubishi Nagasaki Shipyard (1895-1920)
}

\author{
Shinichiro Hagimoto
}

\section{Summary}

The foreign technology introduction to Nagasaki Shipyard provided the evidences that the venture business starting as the independent firm was not always given the advantages. Nagasaki Shipyard as the autonomous unit in Mitsubishi could succeed in the foreign technology introduction and put the shipbuilding industry in developing country on track of increasing returns. It was undeniable that the institutional factors contributed to the path acceleration. These factors, especially the internal capital market, the corporate governance, and the decentralised organisational form (M-form), created the fundamental rules for evolving the business and business unit. This also provided the space and time that enabled the engineers with higher learning to dedicate them to technological development and manufacturing management.

Keywords; M-form, internal capital market, the architecture for the architecture for the organisational growth pattern, increasing returns

\section{Introduction}

Nagasaki Shipyard of Mitsubishi Goshi Kaisha (The Mitsubishi Company) was the first modern factory in the Orient. The shipbuilding of steamships developed apart from traditional Japanese technologies. Before the World War I, Nagasaki Shipyard was the venture business unit that had utilized the technology transfer from the West.

Nagasaki Shipyard started in 1885 when Mitsubishi purchased this former government property as a money-losing dockyard with obsolete repair equipments. Mitsubishi, then an industrial complex of running the mine, collieries and this shipyard across the nation, decided in 1895 to build the Hitachi Maru steamship, the then largest steamship built in Japan (6,172 tons). Since Mitsubishi was then constrained its technology, Mitsubishi was given the opportunity under the condition that the price was much as the homo-type ship built by British shipbuilder. In 1898, this shipbuilding and the manufacturing of engine were completed successfully without non-Japanese engineers or skilled workers.

There came the breakthrough in the field of machinery industry in Japan. In 1904, Mitsubishi made the decision of introducing the foreign technology of marine turbine engine. In 1906, it got the exclusive right to produce and distribute the turbine engine for the dynamo-electric generator. In 1909, Nagasaki Shipyard became successful for the production of marine turbine engine $(9,000 \mathrm{hp})$ and the generator $(500 \mathrm{kw})$ that were the first of those in Japan. This kind of technology import laid the foundation for the development of the internal combustion and electrical machine industries of Mitsubishi. Subsequently, all of the four generators manufactured in 1909 were delivered to and set up in the mines that Mitsubishi owned. In 1911, Nagasaki Shipyard constructed Shunyo Maru (13,000 ton) with the homemade Persons Turbine engine (20000 hp), which was the then largest ship with this type of engine.

In terms of the technology transfer, the 
case of Nagasaki Shipyard provided the significant evidence of the relationship between importing foreign technology and management. This resulted mainly from two attributes of Nagasaki Shipyard. Firstly, Nagasaki Shipyard developed as one of the autonomous units governed by the Mitsubishi head office. This venture business was established within the firm with Multi-divisional form ( $M$ form) of organisation. Especially, the investment fund for this venture business unit was raised through internal capital market. Mitsubishi had been diversified and had a highly profitable business (mining business) that had been expanding. This was in contradiction to the firm that had been specialized in shipbuilding whose investment fund was exposed to the circumstances of the capital market. For the technology transfer in developing countries, there were two paths to developing the venture business, which were different from the alternative of the nationalisation or the privatisation. The alternative paths of the independent firm or the autonomous business unit whose investment fund was supplied through internal capital market were the issue that $M$. Porter, the writer of 'the Competitive Advantage of the Nations' mentioned little. The choice out of the paths formed the path dependency, and influenced the path acceleration

The second attribute to be mentioned had much to do with the origin and evolutionary pattern of the management in Nagasaki Shipyard. Mitsubishi had already formed the architecture for evolving the organisational form and business routines indigenously by the start of Nagasaki Shipyard. There was no imitative learning in the emergence of fundamental rules of the management.

The foreign technology introduction to Nagasaki Shipyard was the case of the established internal capital market and of the practical absence of importing the foreign management. Consequently, this technology introduction resulted in the breakthrough that the naval engineering could catch up with the West at the moment of the take-off of the Japanese economy before the World War I. It also got prepared for the technological basis to take advantage of the industrial and economic expansions in the unprecedented boom during the War. Furthermore, the imported technology of constructing steamship provided the base of the diversification into the full-fledged engineering and electric machinery industry in Mitsubishi after the World War I.

From the beginning of the constructing the Hitach Maru to the end of the boom (1895-1920), the engineers with higher learning employed by Mitsubishi devoted themselves to solve technical problems, although some managers, all of who were from engineering backgrounds, took charge in the manufacturing management. In short, the practice of management in Mitsubishi would not intentionally burden engineers with managerial and political problems.

The foreign technology introduction triggered technological innovation in this period, because the production capacity and the management capability advanced by leaps and bounds and evolved. The total amount of the constructed ships increased from 1,592 ton (in 1987) to 76,995 ton (in 1920), in the period from 1895 to 1920; the number of the employee with higher learning, almost all of them engineers, increased from 103 to 2,964 ; the number of the workers increased from 1,749 to 30,110 .

It was the focused issues that how Mitsubishi managed the innovation triggered by the foreign technology introduction, and what were the 
contributing factors for the innovation under the condition of the established internal capital market and the proprietary managerial institutions. The foreign technology introduction before World War I inevitably led to the overall construction of the factory management system, which was the shaping of the Japanese-style management in Mitsubishi's ingenious way. It is the theme in this research to investigate the prerequisite and contributing institutional factors for the increasing returns and path acceleration.

\section{Internal Capital Market}

Mitsubishi could make the heavy investment in Nagasaki Shipyard for three times before World War I. The concentrated investment was to lay and strengthen the base of technologies for the shipbuilding industry that had been run in the red and to accelerate the speed of development. The fund was available from a highly profitable business. The mining and coal grew rapidly through the horizontal expansion, and Mitsubishi introduced the cutting-edge technology into the newly added coal or mine, where the collective and shared resources could accumulate through the technological and managerial experiences became the source of growth and were diverted to the new mine or coal. This pattern of contriving the increasing return gave the path acceleration to the mining. The outcome of highly profitable business could be interconnected through internal capital market and achieved the growth close to the shipbuilding industry's potentiality in time for the boom. Nagasaki Shipyard had never suffered from the fund shortage, kept away from the sanctions and constrains originated from the external capital markets, and saved the transaction costs in fund-raising.

\section{The architecture for the organisational growth} pattern

The internal capital market was a tool for allocating funds. However, the execution of concrete strategic investment required decision making that were constrained by the governance structure. It was the constitutional rule that the only owner manager as the president had the absolute discretion of strategic issues. This simple structure of line authority at the top level helped save the cost of negotiations. At an initial stage, the owner managers actually relegated the person opposite to the huge amount investment in shipbuilding with the special treatment.

Although Mitsubishi became the limited partnership, and the number of partners was two or three, the management prerogative was delegated to the only one owner manager, the president on the basis of the agreement among the partners. Additionally, it was also the constitutional part of the agreement that the members of the founder's families were not permitted to become a manager in Mitsubishi.

The corporate governance with the high concentration of the ownership could be preventive of the opportunism among the managers and saved the cost of negotiation in the firm. The well-considered limitation of the family members' participation consequently led the firm whose managers were professional managers to bar exceptions of the president. The engineers and managers could buckle down to work professionally. The frames of space and time given to Nagasaki Shipyard were practically identical with those of the 'modern business enterprise', which A.D. Chandler defined.

The decentralised form of the internal 
organisation was part of the architecture for the growth pattern. For example, the general manager of Nagasaki Shipyard was entirely delegated the authority of decision making for operating and advancing the proposal on any strategic issues. The autonomous regional unit known as 'Bashyo (the Place)' was given the business recourses, the delegated authority and income statement account.

This formed the growth pattern in the geographical expansions of the market and diversification. The physiognomic formula of implementing the strategies was to add the new autonomous business unit. For example, the electric machinery industry in Mitsubishi started with the independent factory within 'Bashyo (the Place)' became the 'Bashyo (the Place)' under the direct control of the president, and finally reformed into the subsidiary firm. Basically, the growth pattern in Mitsubishi was the internal growth, in which the collective and shared technological and managerial resources were transferred and transplanted the new business or market. The business capabilities accumulated in Nagasaki Shipyard were transplanted to Kobe Shipyard that was established in 1908 with the aim of expanding the market for ship repairing and shipbuilding and of diversifying into machinery industry on a large scale. There was a simple coherence between the physiognomic formula of evolving business unit and the pattern of diverting or transferring the resources on business. The multi-divisional form with the simple and coherent rules for the putting the growth on track was the accelerator of increasing returns.

\section{The other factors}

The nature of shipbuilding industry should be mentioned, because this industry was vulnerable to the technological problems and was creative of the path dependency. The shipbuilding could start under the condition that all the materiel and mechanical equipments imported from Britain. Furthermore, there were no investments in distribution system and marketing. The domestic market for the ship was advantageous as far as technological progress in Nagasaki Shipyard overcame the backwardness in the price competitiveness, because Japanese shipping firm were developing.

On the other hand, the development of the higher education and the property right were very important factors for the growth of the firm.

\section{Conclusion}

The venture business that triggered foreign technology introduction could choose the alternative path to develop in the firm. This necessitated the some conditions, among them very important were institutional factors, which consisted of the internal capital market, the corporate governance, and the decentralised organisational form (M-form). This implied that the backwardness in technology didn't always mean the backwardness in the quality of management.

The case of Nagasaki Shipyard provided the evidences that the Zaibatsu was the incubator of the venture business

\section{References}

Mitsubishi Jukogyo Kabushiki Kaisha (1960) Shashi Shiryo (Materials on the history of the firm -Recollections)

Mitsubishi Goshi Kaisha (1913) Reiki Ruisan ( The codification of the bylaws in Mitsubishi )

Mitsubishi Shashi Kankokai (ed.) (1972), Mitsubishi Shashi 1-40 (1870-1952), Tokyo 